\title{
Academic Staff Turnover Intention in Madda Walabu University, Bale Zone, South-east Ethiopia
}

\author{
Ibrahim Yimer ${ }^{1}$, Rahel Nega ${ }^{2} \&$ Gemechu Ganfure ${ }^{3}$ \\ ${ }^{1,3}$ College of Medicine \& Health Sciences, Department of Midwifery, Madda Walabu University, Ethiopia \\ ${ }^{2}$ College of Medicine \& Health Sciences, Department of Nursing, Madda Walabu University, Ethiopia \\ Correspondence: Ibrahim Yimer, College of Medicine \& Health Sciences, Department of Midwifery, Madda Walabu \\ University, Ethiopia. E-mail: ibrahmy23@gmail.com
}

Received: February 13, 2017

Accepted: March 10, 2017

Online Published: May 9, 2017

doi:10.5430/ijhe.v6n3p21

URL: https://doi.org/10.5430/ijhe.v6n3p21

\begin{abstract}
Turnover is a voluntary cessation of membership of an organization by an employee. Employee retention is one of the challenges facing several organizations in both the developed and developing countries of the world. It is profitable to proactively react for possible staff turnover intentions. This research was carried out to determine the prevalence of academic staff turnover intention and the factors contributing for it among Madda Walabu University academic staff. An institution based cross-sectional study involving both qualitative and quantitative data collection methods was employed. A structured self-administered questionnaire was used to collect the quantitative data from the respondents. A semi-structured questionnaire, guided by a trained interviewer was used to collect data from an in-depth interview. The interview was carried out on six purposively selected faculty members. The data obtained from both methods were triangulated in the discussion. Binary and multiple logistic regression analysis was used using SPSS version 16. A total of 217 academicians responded to the questionnaire. One hundred sixty four, (75.6\%) respondents intended to leave Madda Walabu University and $24.4 \%$ of academic staff intended to retain their position or post. A bad work environment (lack of facilities like offices, chairs, internet and toilets) was the most frequently cited reason for leaving $(71.3 \%$ ) followed by $63.4 \%$ due to poor management and leadership and $63.4 \%$ due to inadequate salary. Academic staff who had worked five or more years in Madda Walabu University were 4.5 times more likely to leave their institution [AOR $=4.5,95 \%$ CI: $1.37,14.9]$. The prevalence of academic staff intending to leave was found to be very high and as a result, Madda Walabu University will be in an alarming state of staff turnover. Before this happens, there should be staff retention mechanisms in place to improve the work environment, management and leadership and remuneration methods to retain senior and skilled academicians.
\end{abstract}

Keywords: Turnover Intention, Academic Staff, Madda Walabu University

\section{Introduction}

Turnover is viewed as a voluntary cessation of membership of an organization by an employee of that organization. It results from a combination of working conditions, organizational and psychological factors interacting with each other to affect employee attitudes in and toward the organization (Morrell, $\mathrm{K}$ et al., 2001, Bernardo, M et al., 2012).

Employee retention is one of the challenges facing many organizations in both developing and industrialized countries (Ng'ethe JM, Iravo ME \& Namusonge GS, 2012).

As a result of the high employee turnover, managers are facing of shortage skilled manpower for achiving organizational goals. Retention of academic staff will help universities accomplish their vision and mission and become centers of excellence. Public Universities are operating in a highly competitive environment which requires them retain their employees in order to get competitive advantage (Ng'ethe JM, 2012).

The unique nature of universities expects them to be a repository of the most specialized and skilled intellectuals. They serve as storehouses of knowledge for nurturing the manpower needs of the nation. The number and quality of academic staff makes the difference in university education. As a result, higher education institutions are more dependent on the intellectual and creative abilities and commitment of the academic staff than most other organizations. This makes it critically important to retain this cadre of staff (Ng'ethe JM, 2012, Michael O et al., 2013). 
Employees are more likely to remain within an organization if they believe that their managers show interest and concern for them, if they know what is expected of them, if they are given a role that fits their capabilities and if they receive regular positive feedback and recognition (Ng'ethe JM, 2012).

The most serious consequences of a high academic staff turnover are it diminishes teaching quality and student achievement (Surbhi Jain, 2013).

A small study conducted in Ethiopia looking at University faculty attrition to be extremely high. Research conducted in Central and Western Ethiopian Public Universities showed that maintenance of good participation in decision making, well coworker relationships, better working conditions, fixing an attractive payment system, introducing a better promotional ladder and making universities more conducive for instructors in order to diminish turnover intentions (K. John \& Zerihun A., 2014).

The purpose of the study was to determine the magnitude of academic staff turnover intention and the factors contributing for it among Madda Walabu University academic staff. It has shown the various measures to be taken to alleviate the high prevalence of university academic staff turnover intention in accordance with the identified driving factors.

\section{Methods and Materials}

This study was conducted in May and June 2014. Madda Walabu University (MWU) is one of the second generation Universities located in southeastern Ethiopia. It was established in 2007 and consists of one college (College of Medicine and Health sciences), one institute and ten schools. According to the 2013/2014 MWU human resource management report, 621 academic staff were in post excluding expatriate staff and local instructors seconded elsewhere. An institution based cross-sectional study involving qualitative and quantitative data collection methods was employed. All health and non-health academic staff of MWU were the source population. Expatriate academic staff and non-academic staff were excluded from this study. Academic staff turnover intention was the dependent variable. The number of years in post (service years), marital status, religion, age, monthly income, justice, work environment, training and development, autonomy, leadership and promotion were the independent variables.

To determine the sample size, a single population proportion formula using a prevalence of academic staff turnover intention at 50\%, aconfidence level (CI) of 95\%, and a 5\% degree of precision, totaling a 384 samples. Since the source population was less than 10,000 , a correction formula was used to adjust the sample size appropriate to the source population and adding a $10 \%$ non-response rate, totaling a sample size of 271 . Ethical clearance and permission was obtained from the ethical review committee of MWU. Formal written consent was also obtained from the study participants and the name of the respondents was not disclosed in anyway.

The study participants were randomly recruited proportionally from each school, an institiute and the college of medicine and health sciences. This study used a multi-method approach in order to validate the data. A structured self-administered questionnaire was used to collect the quantitative data from the respondents. A semi-structured questionnaire, guided by a trained facilitator/interviewer was used to collect data from an interviewee in an in-depth discussion. The interview was carried out on six purposively selected faculty/administrative members. The data obtained from both methods were triangulated in the discussion. Data was entered and analyzed using SPSS version 16. Binary and multiple logistic regression was done to determine the effect of independent variables on the dependent. Adjusted odds ratios (AOR) with $95 \%$ confidence interval and P-value <0.05 were considered statistically significant.

\section{Results and Discussion}

\subsection{Socio-demographic Characteristics of Respondents}

A total of 217 academicians responded to the questionnaire making the respose rate of $80 \%$. The majority of study participants, $204(94.0 \%)$ were males. One hundred fifty six (71.9\%) of study participants fall in the age group of 25-29. Twenty three (10.6\%) and twenty four (11.1\%) fall into the age group of 20-24 and 30-34 respectively. The mean age of the respondents was 27.8 years $(\mathrm{SD} \pm 3.91)$ with the minimum age of 23 years and 47 the maximum. 54.8\% of the respondents were Oromo ethnic group followed by Amhara (27.2\%). 154 (71\%) of the study participants were Christians followed by Muslims 51 (23.5\%).

Among surveyed respondents, 134 (61.8\%) were single and $82(37.8 \%)$ were married. The study has analyzed the highest qualification of academic staff. The majority, 169 (77.9\%) of study participants have a Masters Degree and $48(22 \%)$ have a first degree. Regarding the service experience of academic staff in MWU, 60 (27.6\%) had served for less than two years; $85(39.2 \%)$ for two to four years, while $72(33.2 \%)$ had served for five or more years. 
Table 1. Socio-demographic characteristics of academic staff in Madda Walabu University, 2014

\begin{tabular}{|c|c|c|c|}
\hline Variables & $\mathbf{n}=\mathbf{2 1 7}$ & Frequency & Percentage \\
\hline \multirow[t]{4}{*}{ Age } & $20-24$ & 23 & 10.6 \\
\hline & $25-29$ & 156 & 71.9 \\
\hline & $30-34$ & 24 & 11.1 \\
\hline & $>35$ & 14 & 6.5 \\
\hline \multirow[t]{2}{*}{ Sex } & Male & 204 & 94.0 \\
\hline & Female & 13 & 6.0 \\
\hline \multirow[t]{5}{*}{ Ethnicity } & Oromo & 119 & 54.8 \\
\hline & Amhara & 59 & 27.2 \\
\hline & Sidama & 21 & 9.7 \\
\hline & Tigre & 16 & 7.4 \\
\hline & Others ${ }^{\#}$ & 2 & 0.9 \\
\hline \multirow[t]{3}{*}{ Religion } & Christian & 154 & 71.0 \\
\hline & Muslim & 51 & 23.5 \\
\hline & Others ${ }^{\boldsymbol{B}}$ & 12 & 5.5 \\
\hline \multirow[t]{3}{*}{ Marital status } & Single & 134 & 61.8 \\
\hline & Married & 82 & 37.8 \\
\hline & Divorced & 1 & 0.5 \\
\hline \multirow{2}{*}{$\begin{array}{l}\text { Highest academic } \\
\text { qualification }\end{array}$} & $1^{\text {st }}$ degree & 48 & 22.1 \\
\hline & $2^{\text {nd }}$ degree & 169 & 77.9 \\
\hline \multirow[t]{3}{*}{ Service year } & $<2$ years & 60 & 27.6 \\
\hline & 2-4 years & 85 & 39.2 \\
\hline & $5-8$ years & 72 & 33.2 \\
\hline \multirow{2}{*}{$\begin{array}{l}\text { Satisfaction } \\
\text { current salary }\end{array}$} & Satisfied & 37 & 17.1 \\
\hline & Not satisfied & 180 & 82.9 \\
\hline
\end{tabular}

\subsection{Descriptive Statistics on Respondents' Turnover Intention}

The majority of the respondents, 164 (75.6\%) intended to leave MWU for a variety of reasons and $53(24.4 \%)$ of academic staff intended to continue in their post (Figure 1). 


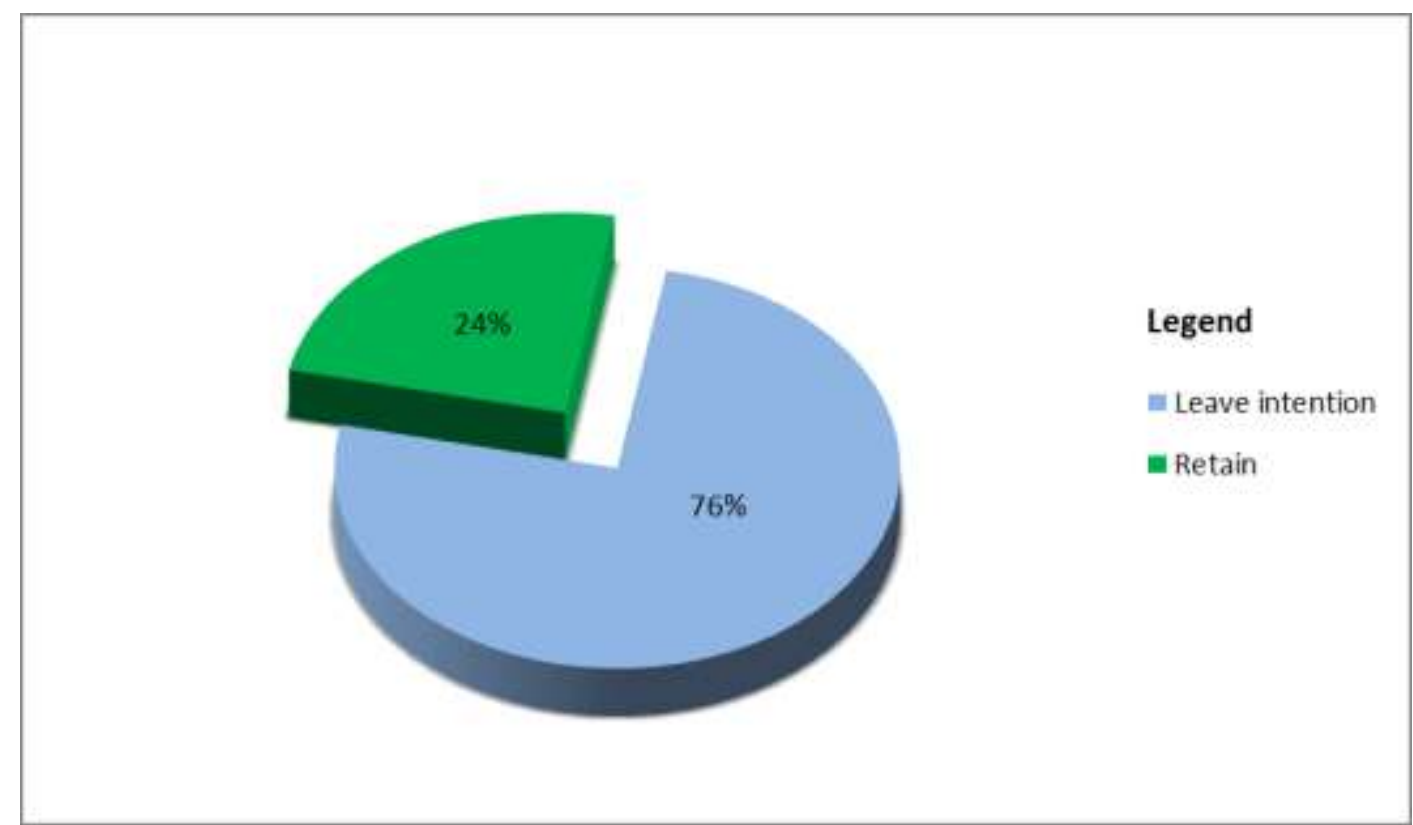

Figure 1. Percentage distribution of intention of academic staff to retain or leave their job in MWU

The College of Medicine and Health sciences instructors had the highest rate of intention to leave MWU 26 (89.7\%) (Figure 2).

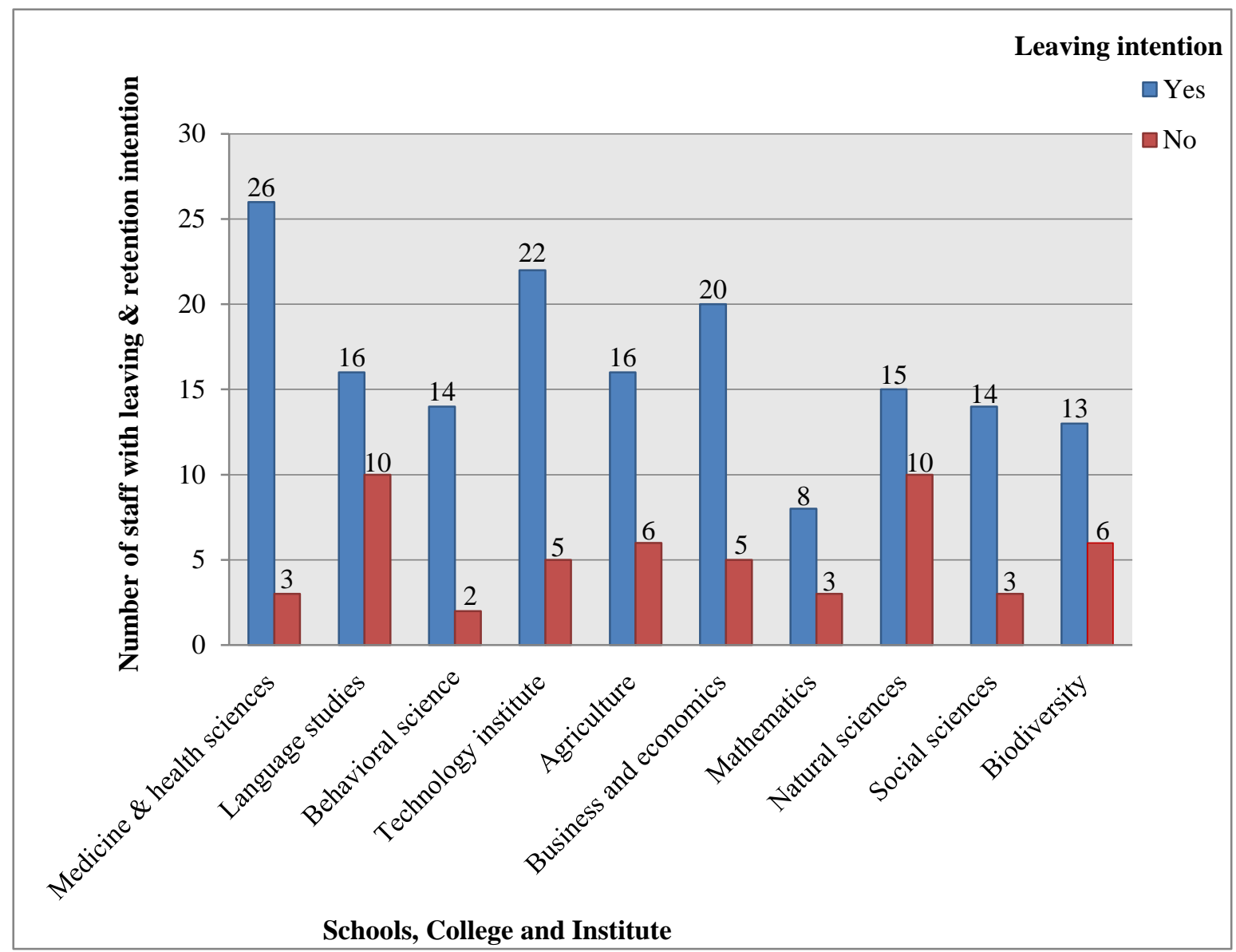

Figure 2. Distribution of academic staff who have leaving

intention and remaining at their institution by College and Schools in MWU. 
More than half (52.4\%) of the study participants who were intending to leave gave the reason as being distant from their family. Bad work environment was the most frequently cited reason for leaving (71.3\%) followed by $63.4 \%$ due to poor management and leadership at department, school, college and university level and $63.4 \%$ due to inadequate salary.

Lack of autonomy and absence of training \& educational opportunities were reported by the study participants as a causes for leaving in $34(20.7 \%)$ and $39(23.8 \%)$ respectively. Fifty seven (34.8\%) and forty six (28\%) of respondents said injustice (unequal distribution of burden and benefits among staff) and absence of recognition for good achievement were factors which would force them to leave (Figure 3).

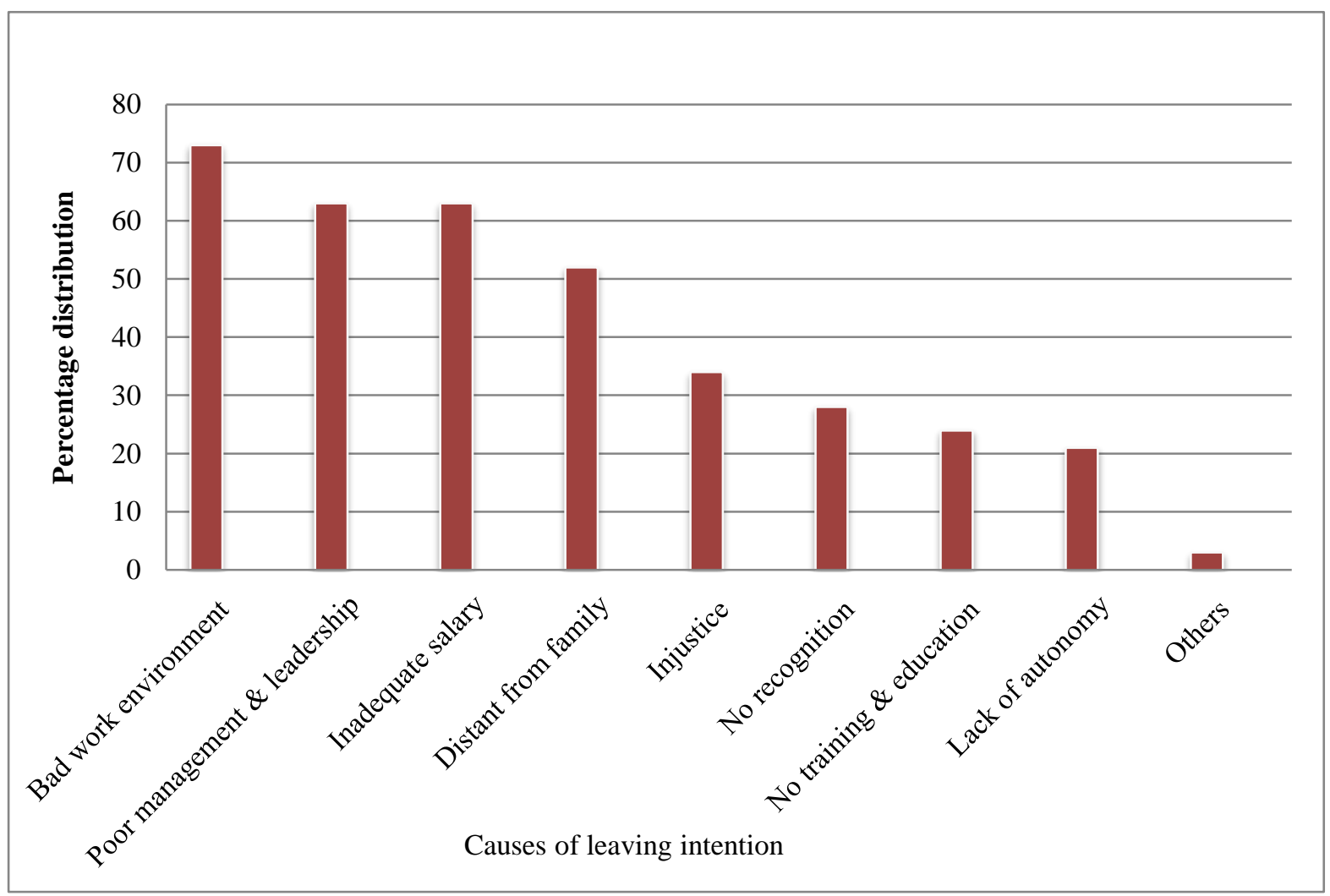

Figure 3. Reasons for leaving intention of academic staff of MWU

This study shows the proportion of the academic staff who have the intention to leave their institution and the determinants of turnover intention in MWU. The prevalence of academic staff turnover intention was found to be $75.6 \%$ (164). This finding is comparable with a similar study conducted in Jimma University in which $65 \%$ of respondents indicated preference to work in other Universities (Workneh. B, 2010). It is also in line with a study conducted in Australian higher education institutions in which $68 \%$ of the academic personnel indicated that they wished to leave higher education (Sanderson, A., Phua, V. \& Herda, D., 2000). The most frequent reason cited by the respondents in the study was the presence of a bad work environment such as lack of computers, internet, offices and chairs, toilets and a staff clinic (71.3\%). An academic staff member stated in an in-depth interview that .....Good work environment is available for administrative staff just forgetting the main academic staff.... This finding is supported by Rosser.V, (2004), who found that the extent to which lecturers feel supported in terms of being provided with adequate and favorable facilities including technology is critically important to the overall quality of their work life and may easily influence their intention to stay or leave.

Poor management and leadership was also found to be the second most important reported cause of turnover intention 104 (63.4\%). An academician reported that "Lack of good management and leadership, for example in terms of non-transparent decisions; presence of double appointment for different positions impacted on turnover intention. 'This finding is comparable with a study done in Jimma University in which incompetent university administration was ranked first (Workneh. B, 2010). This result is also consistent with a study on staff retention in African Universities which revealed that respondents had grievances about structures and processes of governance within their institutions. The criticisms were mostly directed at university-level administrators and systems of authority 
and control. Some unit heads were characterized as dictatorial, insensitive and unresponsive to the needs of their colleagues (W. Tettey, 2006).

Though the salary payment of higher institutions is nationally the same, there is some difference in the current remuneration (extra payment scheme exists) in other Universities. The majority of instructors $(63.4 \%)$ claimed that inadequate salary and other remuneration systems had contributed to their decision to leave.

This finding is parallel with studies which have established that salaries are a very important ingredient inensuring employee commitment to an organization by fulfiling the financial and material desires (K. John \& Zerihun A. 2014, Wyaswa. F \& Katana. G, 2008, Metcalf H, Rolfe P \& Weale M, 2005, Shoaib, M et al., 2009, David M et al., 2004).

Twenty eight percent of study participants' reported that they were not recognized for good achievement. Recognition as stated by academic staff; "Recognition for any activity you achieve has never been considered as long as I have worked in this institution."

This factor was ranked second in contributing for problems of retention in Jimma University staff (Workneh. B, 2010). This might be due to the absence of a reward and appreciation system in both Universities.

This study revealed that gender has no significant association with turnover intention and is in line with the study by Byrd, T. et al, (2000). In other studies however, female employees tend to have a higher intention to leave as compared to male employees (Kim, S., 2005, Yuen-Onn Choong et al., 2013).

Academic staff who have worked five or more years in MWU were 4.5 times more likely to have an intention to leave their institution $[\mathrm{AOR}=4.5,95 \% \mathrm{CI}: 1.37,14.9]$. This finding is supported with an in-depth interview in this study... "Regarding promotion, work experience has no value after you hold a second degree. To make it clear, two academic staff who have a second degree with different work experience have the same promotion regardless of the variation in work experience."Introducing a better promotion ladder is implicated as a way of reducing leaving intentions in central and western Ethiopian public Universities (K. John \& Zerihun A., 2014).

This might be due to work experience being given less attention and/or finishing their duty to receive educational documents so that they can find a post in other Universities or elsewhere (Table 2).

This study revealed single academic staff were three times more likely to leave their post in MWU than married staff $[\mathrm{AOR}=3.04,95 \% \mathrm{CI}: 1.30,7.09]$. This result is supported by different studies in which married employees are more likely to stay in an organization compared to single staff (Yuen-Onn Choong et al., 2013, Salami, S, 2008, Akintayo, D., 2010). 
Table 2. Association of socio-demographic characteristics of academic staff with leaving intention in Madda Walabu University, 2014.

\begin{tabular}{|c|c|c|c|c|}
\hline \multirow[t]{2}{*}{ Variables } & \multicolumn{2}{|c|}{ Leave intention } & \multirow[t]{2}{*}{ COR $(95 \% \mathrm{CI})$} & \multirow[t]{2}{*}{ AOR (95\% CI) } \\
\hline & Yes $(\%)$ & No $(\%)$ & & \\
\hline \multicolumn{5}{|l|}{ Age } \\
\hline $20-24$ & $15(65.2)$ & $8(34.8)$ & $1.875(0.48,7.26)$ & $2.41(0.50,11.50)$ \\
\hline $25-29$ & $124(79.5)$ & $32(20.5)$ & $3.88(1.278,11.9)$ & $3.32(0.95,11.55)$ \\
\hline $30-34$ & $18(75.0)$ & $6(25.0)$ & $3.0(0.74,12.13)$ & $2.83(0.66,12.10)$ \\
\hline$>35$ & $7(50.0)$ & $7(50.0)$ & 1 & 1 \\
\hline \multicolumn{5}{|l|}{ Service year } \\
\hline$<2$ years & $38(63.3)$ & $22(36.7)$ & 1 & 1 \\
\hline 2-4 years & $65(76.5)$ & $20(23.5)$ & $1.88(0.91,3.89)$ & $2.45(0.87,6.89)$ \\
\hline$>5$ years & $61(84.7)$ & $11(15.3)$ & $3.21(1.40,7.36)$ & $4.51(1.37,14.91) * *$ \\
\hline \multicolumn{5}{|c|}{ Academic qualification } \\
\hline 1st degree & $31(64.6)$ & $17(35.4)$ & 1 & 1 \\
\hline 2nd degree & $133(78.7)$ & $36(21.3)$ & $2.03(1.01,4.07)$ & $1.00(0.086,11.61)$ \\
\hline \multicolumn{5}{|l|}{ Marital status } \\
\hline Single & $108(80.6)$ & $26(19.4)$ & $1.93(1.03,3.63)$ & $3.04(1.30,7.09) * *$ \\
\hline Married & $56(68.3)$ & $26(31.7)$ & 1 & 1 \\
\hline \multicolumn{5}{|l|}{ Income } \\
\hline 2000-3999ETB & $28(63.6)$ & $16(36.4)$ & 1 & 1 \\
\hline 4000-6000ЕTB & $136(78.6)$ & $37(21.4)$ & $2.1(1.029,4.288)$ & $1.55(0.14,16.65)$ \\
\hline
\end{tabular}

** Shows significant association at p-value of $<0.05$

\section{Conclusion and Recomendations}

This study revealed that the proportion of academic staff leaving intention was found to be very high. As a result, MWU is in an alarming state of staff turnover/leaving intention. There should be staff retention mechanisms in place such as improving the work environment (offices, chairs, computers, internet and toilets), management and leadership as the problem of university administration is cited as the most prevalent cause; being responsive to staff questions, decentralizing power) and increasing the remuneration rate to retain senior and skillful instructors so that MWU will meet its vision (being one of the top five societal problem solving Universities in the country by 2025 ) is crucial. These factors are useful indicators of actual turnover and provide an opportunity to take actions that might prevent realization of those intentions. MWU should value and recognize academic staff for their contribution by using a variety of mechanisms such as providing feedback, social and material recognition. The University should also take measures that could support academic staff by sharing fruits and burdens in work areas.

\section{Acknowledgements}

The authors acknowledge MWU teachers' association for initiating this opportunity. Great thanks go to the study participants, school directors and department heads for participating and facilitating data collection.

\section{References}

Akintayo, D. (2010). Work-family role conflict and organizational commitment among industrial workers in Nigeria. Journal of Psychological and Counseling, 2(1), 1-8.

Bernardo. M, Macarena G, Raquel R, Ana Isabel S. (2012). A study of physicians' intention to quit: The role of burnout commitment and difficult doctor-patient interactions. Psicothema, 24, 263-270. 
Byrd, T., J. Cochran, I. Silverman, \& W. Blount. (2000). Behind bars: An assessment of the effects of job satisfaction, job-related stress, and anxiety of jail employees inclinations to quit.Journal of Crime and Criminal Justice, 23, 350-360. https://doi.org/10.1080/0735648x.2000.9721123

Kim, S. (2005). Factors affecting state government information technology employee turnover intentions. American Review of Public Administration, 35(2), 137-156. https://doi.org/10.1177/0275074004273150

K. John. \& Zerihun A. (2014). The Impact of Organizational Climate Factors on Turnover Intention of Academic Staff in Central and Western Ethiopian Public Universities. International Journal of Multidisciplinary Management Studies, 4(12), 80-91

Morrell K, Clarke JL, Wilkinson A. (2001). Unweaving Leaving: The Use of Models in the Management of Employee Turnover, Business School Research Series Paper 2001:1. https://doi.org/10.1111/1468-2370.00065

Metcalf. H, Rolfe P, Weale M. (2005). Recruitment and Retention of Academic Staff in Higher Education.National Institute of Economic and Social Research, Research Report RR658.

Michael O. Samuel \& Crispen Chipunza. (2013). Attrition and Retention of Senior Academics at Institutions of Higher Learning in South Africa: The Strategies, Complexities and Realities, 35(2), 97-109.

David Morris, Arzmi Yaacob, Geoff Wood. (2004). Attitudes towards pay and promotion in the Malaysian higher educational sector. Employee Relations, 26(2), 137-150 https://doi.org/10.1108/01425450410511052

Ng'ethe JM. (2012). Influence of leadership style on academic staff retention in public universities in Kenya. International Journal of Business and social sciences, 3(21).

Ng'ethe JM, Iravo ME, Namusonge GS. (2012). Determinants of Academic Staff Retention in Public Universities in Kenya. Empirical Review International Journal of Humanities and Social Science, 2(13), 205-212.

Rosser, V. (2004). Faculty Members' Intention to leave.A national study on their Work- life and $\begin{array}{llll}\text { Satisfaction.Research in Higher } & \text { Education, } & \text { 45(3), 309. }\end{array}$ https://doi.org/10.1023/B:RIHE.0000019591.74425.f1

Salami, S. (2008). Demographic and psychological factors predicting organizational commitment among industrial workers.Anthropologist, 10(1), 31-38.

Sanderson, A., Phua, V. \& Herda, D. (2000). The American faculty poll. TIAA-CREF. New York: National Opinion Research Center, Illinois: Chicago.

Shoaib. M, Noor. A, Tirmizi, S., \& Bashir, S. (2009). Determinants of employee retention in Telecom Sector of Pakistan. Proceedings $2^{\text {nd }}$ CBRC, Lahore, Pakistan,. 14 November, 2009.

Surbhi Jain. (2013). The causes of turnover intention in the employees of educational institutes: an observation: Tactful Management Research Journal, 1(7).

Workneh. B. (2010). Academic Staff Reward System: A Case of Jimma University. Ethiopian Journal of Education \& Science, 6(1).

W. Tettey. (2006). Staff Retention in African Universities: Elements of a Sustainable Strategy, Washington, DC: World Bank.

Wyaswa, F., \& Katana G. (2008). Academic Staff Perspectives on Operating Beyond Industrial Actions for Sustainable Quality Assurance in Public Universities in Kenya.International Journal of Environment, 4(1), 45-58. https://doi.org/10.1504/ijewe.2008.022257

Yuen-On Choong et al., (2013). Impacts of Demographic Antecedents toward Turnover Intention amongst Academic Staff in Malaysian Private Universities. Australian Journal of Basic and Applied Sciences, 7(6), 46-54.

\footnotetext{
Notes

\# Afar, mixed ethnicity (Oromo \& Amhara)

B Wakefetah, atheist
} 